\title{
Linkage analysis of families with severe childhood autosomal recessive muscular dystrophy in Morocco indicates genetic homogeneity of the disease in North Africa
}

F El Kerch, A Sefiani, K Azibi, N Boutaleb, M Yahyaoui, A Bentahila, M-C Vinet, F Leturcq, L Bachner, J Beckmann, K P Campbell, F M S Tomé, M Fardeau, J-C Kaplan

\begin{abstract}
It has been previously shown in Tunisian and Algerian families that the locus for SCARMD maps to the proximal part of $13 q$, and in Algerian families that the disease is associated with deficiency of the $50 \mathrm{kDa}$ dystrophin associated glycoprotein (50DAG). We have tested this linkage in six families from Morocco where this disease is also prevalent. In one family the 50DAG was tested and found to be negative in a muscle biopsy. Our results showed similar linkage in this country, with statistical tests indicating genetic homogeneity between the three Maghreb countries.
\end{abstract}

( $\mathcal{F}$ Med Genet 1994;31:342-343)

Severe childhood muscular dystrophy (SCARMD) is a Duchenne-like form of progressive muscular dystrophy affecting both sexes, first described by Ben Hamida and Fardeau in Tunisia. ${ }^{12}$ This autosomal recessive disease (MIM 253700) is prevalent in Tunisia and Algeria ${ }^{34}$ where it may be as frequent as Duchenne/Becker myopathies. The gene responsible has not yet been identified, but it was recently shown that: (1) in muscle specimens from Algerian patients the sarcolemmal $50 \mathrm{kDA}$ dystrophin associated glycoprotein (50DAG) is absent whereas dystrophin and the other dystrophin associated proteins are normally present ${ }^{5}$; (2) the SCARMD locus maps to $13 \mathrm{q} 12$ by linkage analysis, as shown first in three Tunisian families ${ }^{3}$ and confirmed in 13 Algerian families. ${ }^{6}$

Like Tunisia and Algeria, Morocco belongs to the Maghreb, a geographical region of north west Africa characterised by a common AraboBerberic population with a high frequency of inbreeding. Therefore SCARMD would also be expected to be prevalent in Morocco. Indeed, Duchenne-like families with affected girls are quite frequent in this country ( $M$ Yahyaoui, personal communication).

In the present study we have selected for linkage analysis six well characterised families from Morocco, comprising 18 patients (10 males and eight females) (figure). They were selected on the following obligate criteria: (1) a clinical and pathological pattern typical of SCARMD $^{12}$; (2) multiplex families with at

least one female affected. In addition the diagnosis was further validated by finding 50DAG deficiency by immunofluorescence analysis of one muscle specimen ${ }^{578}$ (patient 8 of family 4, figure). The SCARMD families were genotyped using the following microsatellite markers assigned to the proximal long arm of chromosome 13: D13S221 (AFM $248 \mathrm{wcl})^{9}$ D13S175 (AFM2 49xbl), ${ }^{9}$ and D13S $115,{ }^{10}$ as described in Azibi et al. ${ }^{6}$

The cumulated two point lod scores ${ }^{11}$ obtained with the three markers in the six families and a comparison with the data obtained in 13 families from Algeria $^{6}$ are shown in the table. A search for genetic heterogeneity among the cumulated 19 SCARMD families was carried out with the HOMOG program (version $3.31^{12}$ ) on the three sets of lod score values. No evidence for heterogeneity was found for informative families (data not shown).

The homogeneity of our linkage data in Morocco compared to those previously

1

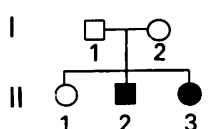

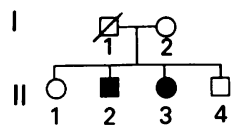

3

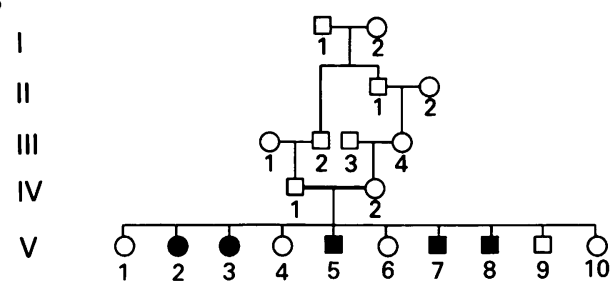

4

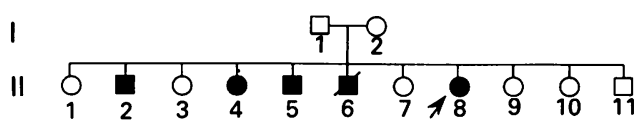

5

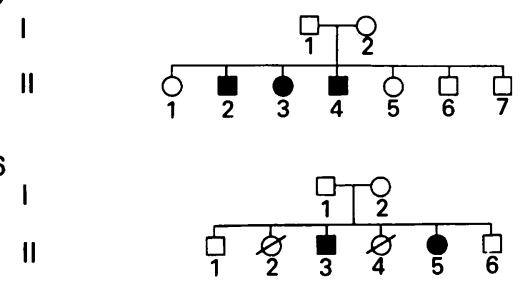

Pedigrees of six families with SCARMD. Arrow indicates patient in whom SODAG was investigated. 
Cumulated lod scores in the six families with SCARMD

\begin{tabular}{|c|c|c|c|c|c|c|c|c|c|}
\hline \multirow[b]{2}{*}{ Marker } & \multicolumn{9}{|l|}{$\theta$} \\
\hline & 0.000 & 0.001 & 0.01 & 0.05 & 0.1 & 0.15 & $0 \cdot 20$ & $0 \cdot 30$ & 0.40 \\
\hline \multicolumn{10}{|l|}{ D13S175 } \\
\hline Morocco* & $-\infty$ & -7.03 & -3.03 & -0.39 & 0.50 & $0 \cdot 81$ & 0.89 & 0.64 & 0.23 \\
\hline Algeria $\dagger$ & $-\infty$ & -9.87 & $-4 \cdot 60$ & $0 \cdot 25$ & 2.00 & 2.49 & 2.43 & 1.59 & 0.56 \\
\hline Cumulated & $-\infty$ & -16.90 & -7.63 & $-0 \cdot 14$ & $2 \cdot 50$ & $3 \cdot 30$ & $3 \cdot 32$ & $2 \cdot 23$ & 0.79 \\
\hline \multicolumn{10}{|l|}{ D13S221 } \\
\hline Morocco* & $-\infty$ & -5.31 & -1.35 & $1 \cdot 15$ & 1.85 & 1.96 & 1.82 & $1 \cdot 15$ & 0.37 \\
\hline Algeria $\dagger^{-}$ & $-\infty$ & -8.85 & -2.98 & 1.43 & $2 \cdot 64$ & $2 \cdot 78$ & 2.51 & 1.56 & 0.61 \\
\hline Cumulated & $-\infty$ & $-14 \cdot 16$ & $-4 \cdot 33$ & $2 \cdot 58$ & $4 \cdot 49$ & $4 \cdot 74$ & $4 \cdot 33$ & $2 \cdot 71$ & 0.98 \\
\hline \multicolumn{10}{|l|}{ D13S115 } \\
\hline Morocco* & $-\infty$ & -5.54 & -0.63 & $2 \cdot 36$ & 3.08 & $3 \cdot 10$ & $2 \cdot 83$ & 1.79 & 0.60 \\
\hline Algeria $\dagger^{\dagger}$ & $-\infty$ & -4.85 & -1.34 & 1.60 & 2.45 & 2.49 & $2 \cdot 21$ & 1.37 & 0.58 \\
\hline Cumulated & $-\infty$ & $-10 \cdot 39$ & -1.97 & 3.96 & 5.53 & $5 \cdot 59$ & 5.04 & $3 \cdot 16$ & $1 \cdot 18$ \\
\hline
\end{tabular}

* This study

+13 families of Azibi et al. ${ }^{6}$
2 Ben Hamida M, Fardeau M, Attia N. Severe childhood muscular dystrophy affecting both sexes and frequent in Tunisia. Muscle Nerve 1983;6:469-80.

3 Ben Othmane K, Ben Hamida M, Pericak-Vance M, et al. Linkage of Tunisian autosomal recessive Duchenne-like muscular dystrophy to the pericentromeric region of chromosome 13q. Nature Genet 1992;2:315-17.

4 Azibi K, Chaouch M, Reghis A, et al. Linkage analysis of 19 families with autosomal recessive (Duchenne-like) muscular dystrophy from Algeria. Cytogenet Cell Genet 1991;58:1907.

5 Matsumura K, Tomé FMS, Collin $\mathrm{H}$, et al. Deficiency of the $50 \mathrm{~K}$ dystrophin-associated glycoprotein in severe childhood autosomal recessive muscular dystrophy. $\mathrm{Na}$ childhood autosomal

6 Azibi K, Bachner L, Beckmann JS, et al. Severe childhood autosomal recessive muscular dystrophy with the deficiency of the $50 \mathrm{kDa}$ dystrophin-associated glycoprotein maps to chromosome 13q12. Hum Mol Genet 1993;2:1423-8.

7 Ohlendieck K, Campbell KP. Dystrophin-associated proteins are greatly reduced in skeletal muscle from $m d x$ mice. $\mathcal{J}$ Cell Biol 1991;115:1685-94.

8 Ohlendieck K, Matsumura K, Ionasescu VV, et al. Duchenne muscular dystrophy: deficiency of dystrophinassociated proteins in the sarcolemma. Neurology 1993;43:795-800.

obtained in Tunisia and Algeria suggests that SCARMD may be the result of the same defective gene and possibly the same mutation in all three Maghreb countries. This is not surprising because of the common origin of these populations. It would be interesting to determine whether the same locus is involved in SCARMD outside North Africa, ${ }^{13-15}$ and ultimately to define whether the 50DAG defect is primary or secondary to the gene defect. This work was supported by the Association Française contre
les Myopathies. We are grateful for the invaluable help of the Association Marocaine contre les Myopathies (Mr M I Alaoui) Association Marocaine contre les Myopathies (Mr M I Alaoui), and the Cooperation Division of the French Embassy in Rabat. We thank Professor $M$ Hassar for his support. KPC
Investigator of the Howard Hughes Medical Institute.

1 Ben Hamida M, Fardeau M. Severe, autosomal recessive, limb-girdle muscular dystrophies frequent in Tunisia. Exc Med Muscular Dystrophy Research 1980;527:43-146.
9 Weissenbach J, Gyapay G, Dib C, et al. A second-generation linkage map of the human genome. Nature 1992;359:794-801.

10 Hudson TJ, Engelstein M, Lee MK, et al. Isolation and chromosomal assignment of 100 highly informative human simple sequence repeat polymorphisms. Genomics 1992;13:622-9.

11 Lathrop M, Lalouel JM, Julier C, Ott J. Multilocus linkage analysis in humans: detection of linkage and estimation of recombination. Am f Hum Genet 1985;37:482-98.

12 Ott J. Analysis of human genetic linkage. Baltimore: The Johns Hopkins University Press, 1991.

13 Farag TI, Teebi AS. Duchenne-like muscular dystrophy in the Arabs. Am $\mathcal{7}$ Med Genet 1990;37:290.

14 Salih MAM, Omer MIA, Bayoumi RA, Karrar O, Johnson $M$. Severe autosomal recessive muscular dystrophy in an extended Sudanese kindred. Dev Med Child Neurol 1983;25:43-52.

15 Fardeau M, Matsumura K, Tomé FMS, et al. Deficiency of the $50 \mathrm{kDA}$ dystrophin associated glycoprotein (adhalin) in severe autosomal recessive muscular dystrophies in children native from European countries. C R Acad Sci III 1993;316:799-804. 